\title{
BREAKING WINDOWS: MALAYSIAN MANGA AS DRAMATURGY OF EVERYDAY-DEFINED REALITIES
}

\author{
Rachel CHAN Suet Kay \\ National Institute of Ethnic Studies (KITA), \\ National University of Malaysia (UKM) \\ (rachelchansuetkay@ukm.edu.my) \\ DOI: https://doi.org/10.22452/jati.vol23no2.10
}

\begin{abstract}
The consumption of Japanese anime and manga among Malaysian readers has increased in the past decade (Roslina Mamat, Yamato Eriko, Sanimah Hussin, \& Farah Tajuddin, 2012). Currently, Malaysian youth have reached an advanced stage of manga consumption, creating original works (Roslina Mamat, Yamato Eriko, Sanimah Hussin, \& Farah Tajuddin, 2012). For example, Malaysian manga artist, Kaoru was the first to earn acclaim among local manga consumers and paved the way for other new entrants to the mangaka scene (Gan, 2011). However, manga has also been described as "culturally odourless" by Iwabuchi (1998). Gan (2011) notes that a significant aspect of Kaoru's work is a narrative context that is devoid of a fixed locality, instead of occupying an ambiguous and imaginative space, which enables the creation of a "place free from the ethnic tensions of everyday life". I add on to this discourse by observing that there is now a new wave of Malaysian made manga that roots itself in locally recognisable depictions of standard ethnicity, gender, and social class dimensions. In doing so, I extend a content analysis into a specific manga publication, called Kepahitan Tersembunyi by Dreamerz and Leoz, published under Gempak Starz. I argue that this particular manga novel reaches beyond the suspended reality of Kaoru's narrative world, into a recognisable Malaysian landscape, for example through the depiction of Malaysian school uniforms. I highlight the way stylistic elements of manga are used to signify identifications of ethnicity, gender, and social class in a way that is recognisable to the Malaysian reader. This suggests that manga may be seen as a platform for the dramaturgy of "everyday-defined" realities (Shamsul Amri Baharuddin, 1996).
\end{abstract}

Keywords: everyday-defined realities, dramaturgy, Malaysia, ethnicity, culturally odourlessness 


\section{Introduction}

Manga is now one of the most recognised forms of popular culture worldwide. It is a hybrid form whose origins can be traced to a combination of influences from the East and the West (Bryce, Barber, Kelly, Siris Kunwar \& Plumb, 2010). In Japan, it is said that emakimono, or rolls of illustrations that accompany a story, developed in 12th century Japan as a narrative technique (Fusanosuke, 2003). This was also linked to the method of printing from woodblock panels in the $17^{\text {th }}$ century, known as ukiyo-e or "pictures of the floating world" (Brenner, 2007). It is also possible that manga has had influences from early Chinese civilisation (Schodt, 1983), as East Asian cultures have had a relatively close picture-to language relationship (Fusanosuke, 2003). The renowned Japanese animator, Tezuka Osamu openly acknowledged the influences of early Walt Disney and Max Fleisher in his work (Wong, 2006).

Common characteristics of Japanese manga include unique contemporaneous sensibilities, narrative approaches, and drawing style (Gan, 2011). These include a harmony of linguistic elements, flexible frames and speech bubbles, and iconographic images (Bryce et al., 2010). Manga's trademark style was influenced by American newspaper comics, with multiple frames, dialogue in balloons, and narration (Fusanosuke, 2003). Cohn extended the definition of manga beyond big eyes and "backward" reading, to include Japanese Visual Language (JVL) that comprises the "manga style", examining the graphic emblems that form manga's conventional visual vocabulary (Cohn, 2008). In doing so, he disputes the emakimono thesis, instead concluding that these historical similarities are superficial, and that "it was only through the influence of American comics that Japan began to engage in conventions like multiple panels" (Gravett, 2004; Kinsella, 2000). To understand manga, thus, the cultural capital needed is a distinct kind of literacy, which is to connect description, dialogue, image, symbols, and the sequence of panels into a coherent story (Brenner, 2007).

Manga genres are categorised based on the age and gender of its target readers, for example, shonen manga (for teenage boys), shojo manga (for teenage girls), josei manga (for women), and seinen manga (for men), among many others (Wong, 2006). The appeal of manga lies in its sheer variety of genres (Brenner, 2007). Manga and anime present consumers with an appealing choice of familiarity and difference (Bryce et al., 2010). The familiarity occurs because the plot, experiences, or emotions reflect the reader's, regardless of ethnicity or nationality, and takes place in no distinct culture (or those that appear “Caucasian”) (Allison, 2000; Levi, 2006; Napier, 2007; Newitz, 1995; Norris, 
2005). The difference occurs because they incorporate elements which are unique to other forms of comic art, e.g. visual style, narrative structure, character types, plot development etc. (Bryce et al., 2010).

\section{Literature Review}

In the past few decades, the demand for manga has grown exponentially in Southeast Asia. Throughout the South East Asian region, Japanese influence permeates the sphere of cartoons and comics, with bookstores stocking many Japan-originated titles, locally published manga appearing, and South East Asian cartoonists imitating the Japanese style (Lent, 2007).

Likewise, the consumption of Japanese manga among Malaysian readers has been incremental in the past decade (Roslina Mamat, Yamato Eriko, Sanimah Hussin, \& Farah Tajuddin, 2012). The global manga phenomenon had encouraged the production of comics amongst local entrepreneurs and creators, sprouting many relatively new companies such as the Art Square Group in Malaysia (Lent, 2007). Beyond merely reading the manga, Malaysian youth have now reached an advanced stage of manga consumption, participating in the creation of their original works (Roslina Mamat et al., 2012). Gan, for instance, highlighted a landmark Malaysian manga artist (mangaka), Kaoru, who was the first such comic artist to earn acclaim among local manga consumers, besides having paved the way for other new entrants to the mangaka scene (Gan, 2011). This is facilitated by the existence of local comics publisher, Gempak Starz. On the amateur front, there are Malaysian teenagers who proudly claim to have their team working towards publishing their manga in the form of sketches on paper or by using certain software (Roslina Mamat et al., 2012).

However, manga has also been described as "culturally odourless" by Iwabuchi. By "culturally odourless", Iwabuchi refers to the "suppression of Japanese cultural odour to make inroads into international markets", or the absence of identification of characters and settings based on ethnicity. Iwabuchi remarked that when products are shared, the process of translation, adaptation, and/or representation, blurs the boundaries between what is foreign and local, and consumers of manga and anime are not connecting specifically with Japan or Japanese culture. Iwabuchi (1998) observed that the features of the characters in manga and anime, and the contexts in which they appear, usually do not indicate that the narrative occurs in any specific culture or location.

Following the above, Gan (2011) notes that a significant aspect of Kaoru's work is a narrative context that is devoid of a fixed locality, instead of occupying an ambiguous and imaginative space. This enables the creation of a 
"place free from the ethnic tensions of everyday life". I add on to this discourse by observing that there is now a new wave of Malaysian made manga that "breaks windows" where the standard ethnicity, gender, and social class dimensions typical in the manga are depicted.

\section{Theoretical Framework}

This paper uses the "everyday-defined" social reality approach to explain identity formation among Malaysian youth. It thus draws from the call to challenge the legacy of colonial discourse in Malaysian epistemological space, by examining popular narratives, which consist of a medium such as comics (Shamsul Amri Baharuddin \& Athi S. M., 2013, p. 268). Shamsul Amri Baharuddin (1996) explained that identity formation takes place within an "authority-defined" and an "everyday-defined" social reality. The first is authoritatively defined by people who are part of the dominant power structure; and, the second, the "everyday-defined" social reality, is experienced by the people in the course of their everyday life (Shamsul Amri Baharuddin, 1996). These two social realities exist side by side at any given time, where the "everyday-defined" social reality is experienced and the "authority-defined" social reality is only observed and interpreted (Shamsul Amri Baharuddin, 1996). I argue that in order to be relevant to its readers' identity formation, Malaysian manga cannot simply possess the quality of being "culturally odourless", but has to contain some semblance of Malaysian identity markers, which can be experienced from the "everyday-defined" social reality approach. This is what I mean by "breaking windows", which is the narrative extending its reach into social reality.

\section{Research Question}

In this paper, I attempt to address one pertinent question regarding the character of Malaysian manga. Can Malaysian manga be truly Malaysian if it has Japanese influences (Brienza, 2015, cited in Lee, 2018)? However, if it was thoroughly "domesticated", would it still be manga? I thus pose the question whether Malaysian manga is true "culturally odourless" as described by Iwabuchi (1998). In answering the above question, I conduct a content analysis on a specific manga publication, called Kepahitan Tersembunyi (Malay to English translation: Hidden Pain) by mangaka Dreamerz and Leoz (2016), also published under Gempak Starz. I argue that this example is part of the second wave of manga comics in Malaysia, which has transcended the first wave of "culturally 
odourless" manga into something recognisable based on local identity constructs. This, I theorise, is due to manga's already widespread acceptance in Malaysia, where readers are able to reach beyond a fetishisation of Japanese culture into the adoption of its characteristics to create a new lived experience.

\section{Methodology}

In this paper, I highlight the themes found in a content analysis of the manga. The reason for using a content analysis is because of the graphical nature of manga, in which graphic emblems form manga's conventional visual vocabulary, henceforth known as Japanese Visual Language (JVL) (Cohn, 2008). For example, in a large scale study of manga by Douglass, Huber and Manovich (2011), digital image analysis and visualization was utilised for the study of a massive image collection of one million manga pages. Douglass et al. (2011) systematically analysed the visual language of "fan-scanlated" manga, comparing visual differences from original Japanese publications and official English translations. The "scanlation subculture" revolves around the scanning and translating of Japanese graphic novels, or manga (Douglass et al. (2011); in Chan, 2017). They found that the experience of reading "global digital manga" was different from "Japanese print manga", which was in turn different from "global print manga" (Douglass et al., 2011). Hence, I exhibit several scans of the manga of my choice, Kepahitan Tersembunyi (Hidden Pain) as it was marketed in my local chain bookstore as being under the Manga section. These scans are chosen as they depict the identity markers of its characters, and one is thus able to compare between the "culturally odourless" Japanese manga and the localised Malaysian manga. More information about this volume is contained in the findings below.

\section{Kaoru: Malaysian Mangaka with Japanese influences}

"She's been in love with comics ever since she was old enough to grasp a pencil and draw. No wonder she's the first female cartoonist in Malaysia to ever appear with manga influenced style." (Kaoru's Official Facebook Page, n.d.).

One of the biggest success stories of a Malaysian full-time manga artist is that of Kaoru Liew, a Malaysian Chinese born in 1982 in Ipoh, Perak. As of 2018, she will have been a manga artist, or mangaka, for 19 years ("Kaoru's romantic comics", 2016). She began her career as a cartoonist in the Art Square 
Group which publishes the Gempak magazine (Wikipedia Bahasa Melayu, n.d.). One of the most prominent artists in Kadokawa Gempak Starz, she is widely recognised as the first professional female cartoonist in Malaysia ("Kaoru's romantic comics", 2016). In the local manga scene, she is a pioneer who has paved the way for a wave of female manga artists ("Kaoru's romantic comics", 2016).

Her most notable works, among fifty in total, are Helios Eclipse, Kaoru's Cake House, and Maid Maiden. Helios Eclipse is the story of a girl named Mineko who meets a character from another world, called Helios. Helios turns out to be a sorcerer and is one of the leaders of his universe who is being hunted down to be killed ("Helios Eclipse", n.d.). Kaoru's Cake House is the story of four sensitive gentlemen who operate a bakery, and often get into emotional entanglements with their customers ("Kaoru's Cake House", n.d.). Maid Maiden is about Alivia who is searching for Prince Charming, who was once her saviour. However, her parents' bankruptcy does not allow Alivia to enroll at the same school as her Prince. Thus, she has to serve as a maid and lover instead to another rich boy ("Maid Maiden", n.d.). The names of all the characters in these three books are Westernised and so are their appearances.

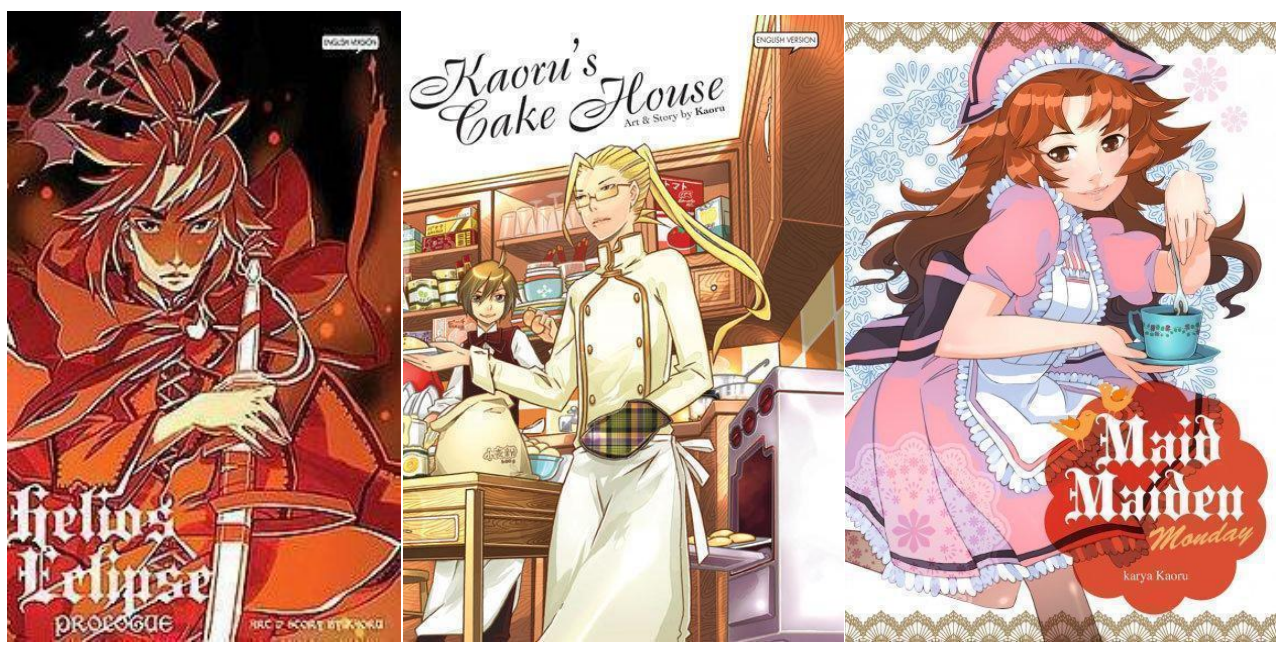

Figure 1 - Helios Eclipse, Kaoru's Cake House, and Maid Maiden

(Source: Kaoru's official Facebook page [n.d.].)

Kaoru specialises in shojo manga, which she describes as for "mostly girls and young women from 14 to 25". Shojo manga emerged in the 1970s and possessed a few distinguishing characteristics, such as a fairy tale European past including escapism, drama, romance, tragedy, and fabulous costumes (Brenner, 2007). When asked about the themes in her stories, Kaoru opines that "I think 
that readers who read romance comics don't read them because they identify with a strong, independent heroine," she continues. "It's just not like that. They may be lonely and looking for a romance that they can't find in the real world." ("Kaoru's romantic comics", 2016). Kaoru herself claims to be inspired by the famous Japanese manga, Slam Dunk ("Kaoru's romantic comics", 2016). She admits that when she first entered the comic scene as an art assistant, the majority of comics were shonen manga, and as the only female artist specialising in shojo manga, she had to work hard to be taken seriously ("Kaoru's romantic comics", 2016). Now a celebrity in the comic world, Kaoru has her own Facebook fan page (Kaoru's official Facebook page, n.d.).

Gan describes Kaoru's manga as demonstrating an "alternative form of local identity" without an apparent "local style" noteworthy in multi-ethnic Malaysia (Gan, 2011). This may well be because Kaoru's works represent the first wave of home-grown manga artists in Malaysia, being that she is the pioneer of this phenomenon. I argue that it would have taken time for Malaysian readers to first appreciate a local alternative comparable to the quality of original Japanese manga. As local readers have found Kaoru and her contemporaries' works to be of significantly high quality, then only did a local demand for Malaysian manga grow.

Hence, this, in turn, paved the way for a new crop of home-grown manga which could now afford to be rooted in local sensibilities. In the next section, I highlight the case of one such manga, which is instantly recognisable as Malaysian from the moment I picked it up off the bookshelf.

\section{Kepahitan Tersembunyi (Hidden Pain): A Localised Malaysian Manga}

To illustrate the existence of the second wave of original Malaysian manga, I chose the manga Kepahitan Tersembunyi (Hidden Pain) as it was marketed in my local chain bookstore as being under the Manga section. This graphic novel is part of a series called Citra Kasih (Images of Love), published by Kadokawa Gempak Starz, Malaysia's premier manga publisher, in December 2016. The manga is written in Bahasa Malaysia, Malaysia's official language. It is conceptualised by Dreamerz and Leoz and authored by Leoz. The editorial board of this comic consists of a multiethnic and multilingual team. The book length is about 150 pages and sells in major Malaysian bookstores, newsstands, as well as online on the publisher's online store for RM 12 (about USD 3) in West Malaysia and RM 15 (about USD 4) in East Malaysia.

The blurb of this book provides this synopsis, which I translated from Bahasa Malaysia into English: "Joel is often bullied by his seniors. This fact is 
known to the prefects, but they turn a blind eye because they do not want to get involved. Joel's patience finally wears thin. He refuses to be bullied anymore and wishes to become stronger. To prove his strength, he starts with...".

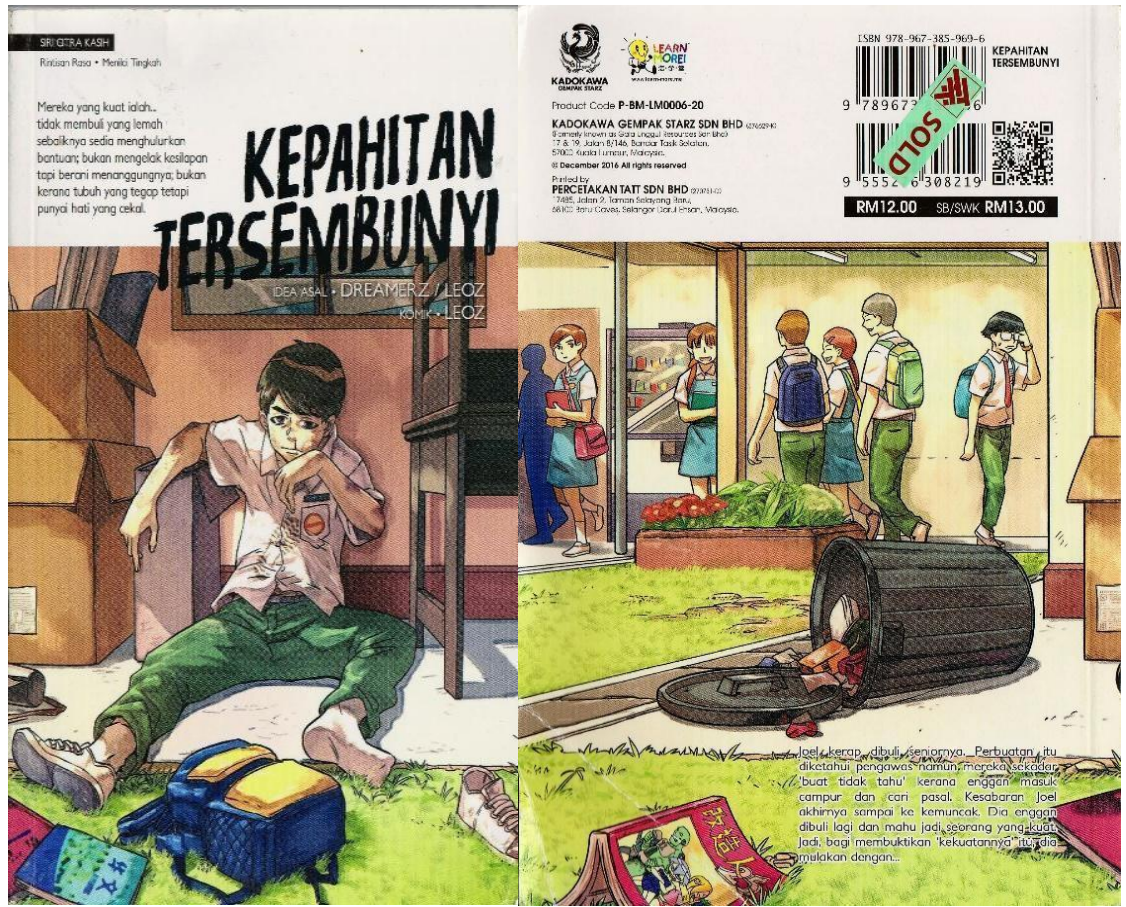

Figure 2 - Front and back covers of Kepahitan Tersembunyi by Dreamerz and Leoz (2016)

(Image scanned from Kepahitan Tersembunyi [Dreamerz \& Leoz, 2016].)

This graphic novel conforms to some standards outlined in the literature regarding manga while differing in certain ways. The manga aesthetic may include a combination of Disneyesque styles (e.g. Tezuka), the precision of mecha (robot manga), or the softness of shojo manga (Johnson-Woods, 2010) In this aspect, Kepahitan Tersembunyi delivers with its previews of the main characters' favourite mecha manga. The manga focuses on one main character (Eijiro Shimada of Kodansha, in Johnson-Woods, 2010) and this is seen on the front cover itself, where the focus is on the main character who is a victim of bullying at school, and also inside where we hear his narrative. Inside, the frames are not always neat rectangles lined up equidistant (Johnson-Woods, 2010). This is indeed the case.

Nonetheless, there are several localised modifications in Kepahitan Tersembunyi. Manga is usually rendered in black and white without the hyper 
coloring of Western comics (Johnson-Woods, 2010). However, in Kepahitan Tersembunyi all pages including the front and back covers are in colour. Manga mimics an Asian reading orientation, from back to front and right to left (Johnson-Woods, 2010). In Kepahitan Tersembunyi, the reading orientation follows the Western style from front to back and left to right, perhaps because it is published in Bahasa Malaysia, which is read similar to English.

The artist, Leoz was born in Taiping, Perak in 1986, and was the winner of the New Comic Book Talent Search in Malaysia in 2005. Their gender is unknown; hence I shall refer to Leoz as "they". They are now a freelance comic artist and comic tutor.

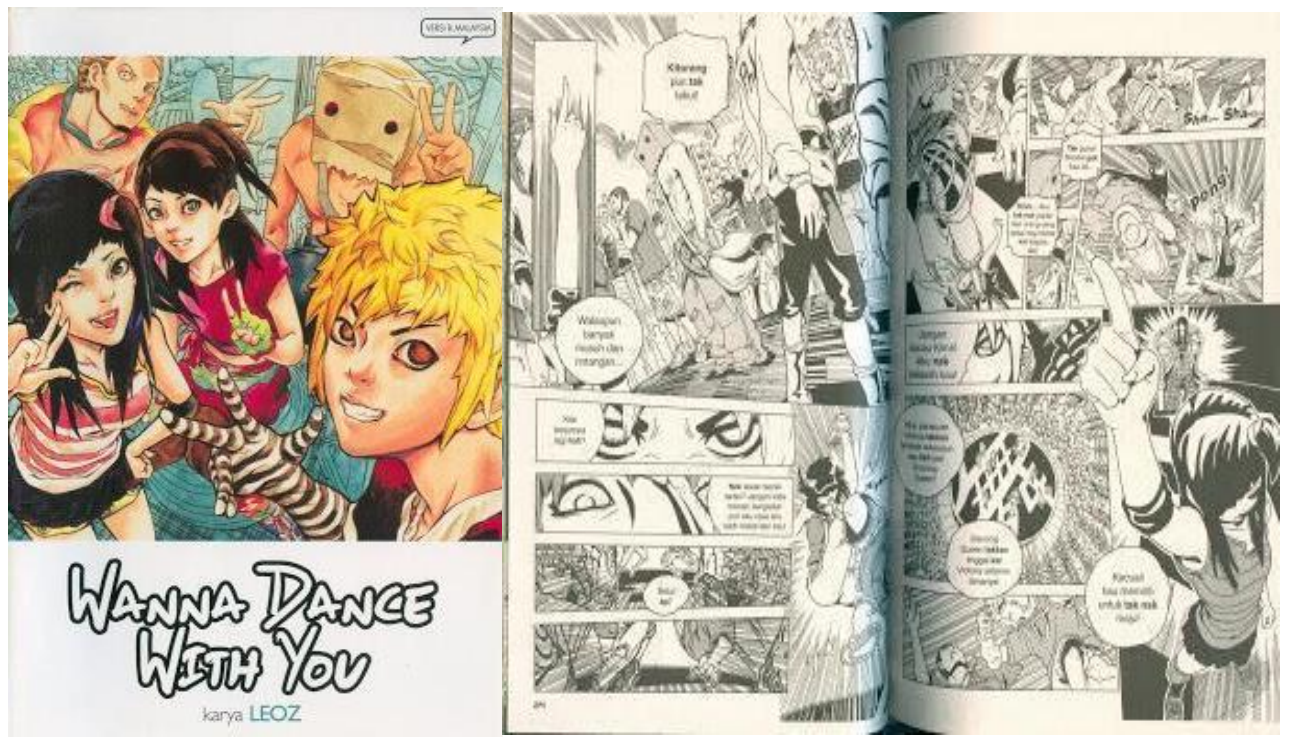

Figure 3 - “Wanna Dance with You" by Leoz ("Wanna Dance with You”, 2009)

In their early days, Leoz had also authored manga which was similar in "cultural odourlessness" to Kaoru's. For example, Leoz's early manga was called "Wanna Dance with You", and as the image below shows, the characters do not belong to any specific ethnicity. According to a blog review of this manga, the language used is Bahasa Malaysia and "rojak", or a mix of other languages ("Wanna Dance with You", 2009). The theme of this manga was "romance" and "slice of life", often veering into fantasy. Leoz was also part of the first wave of original Malaysian manga and has evolved to create more localised content since. 


\section{Themes in Kepahitan Tersembunyi}

\section{Ethnicity}

The main character, Joel Lee, is a schoolboy who likes reading and collecting comics, and is a bully victim. He has a Chinese surname and an English first name, a common occurrence among Malaysian Chinese for a variety of reasons, for example, to ease pronunciation by non-Chinese speakers. His father runs a Chinese "wantan mee" noodle stall which appears to be part of the informal economy, pegging him to the working class. The stall has a signboard with Chinese letters. His father dresses in a typical middle-aged Chinese stall holder style (Pagoda T-shirt, similar to a tank top).

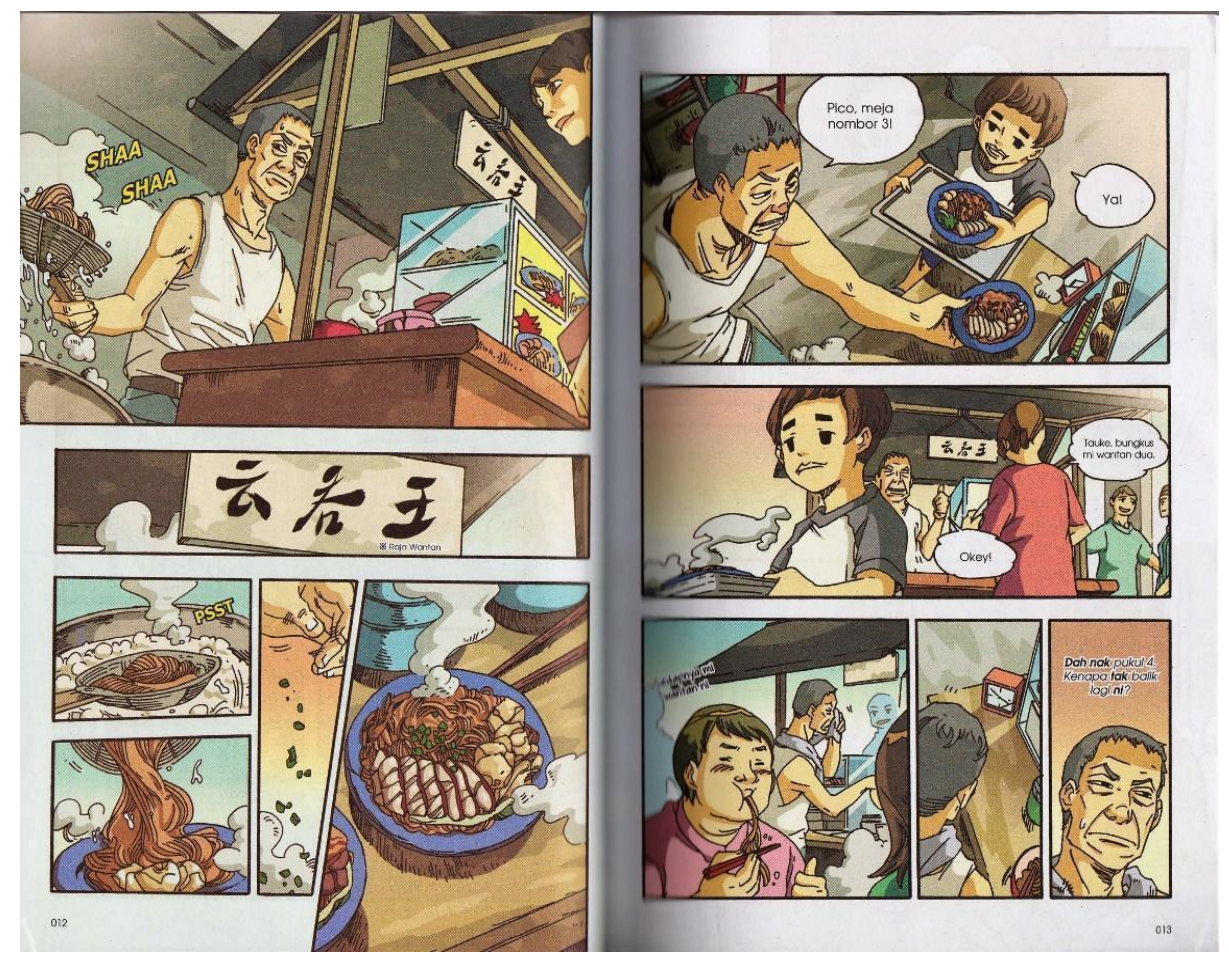

Figure 4 - Main character Joel Lee's father is a Chinese "wantan mee" noodle seller.

(Image scanned from Kepahitan Tersembunyi [Dreamerz \& Leoz, 2016].)

The customers eat with chopsticks, a Chinese eating utensil. The ethnicities of the other characters are not as clearly depicted, and some are not referred to by name. A Chinese song by the Hong Kong rock ensemble Beyond is featured. Books with Chinese lettering are featured. One of the prefects 
displays status loss anxiety as his parents have conditioned him to excel in studies, get a good job, etc., but to stay out of trouble. This is a typical concern and stereotype of certain migrant Chinese families.

\section{Social Class}

Inequality is a recurring theme. The bullies make fun of Joel for having only RM 20 (equivalent to roughly USD 5) in his wallet. Joel's wallet is empty after the bullies leave him. Joel's father runs a Chinese "wantan mee" noodle stall which implies that he is of a low income category. Joel's home is small and shabby with necessities.

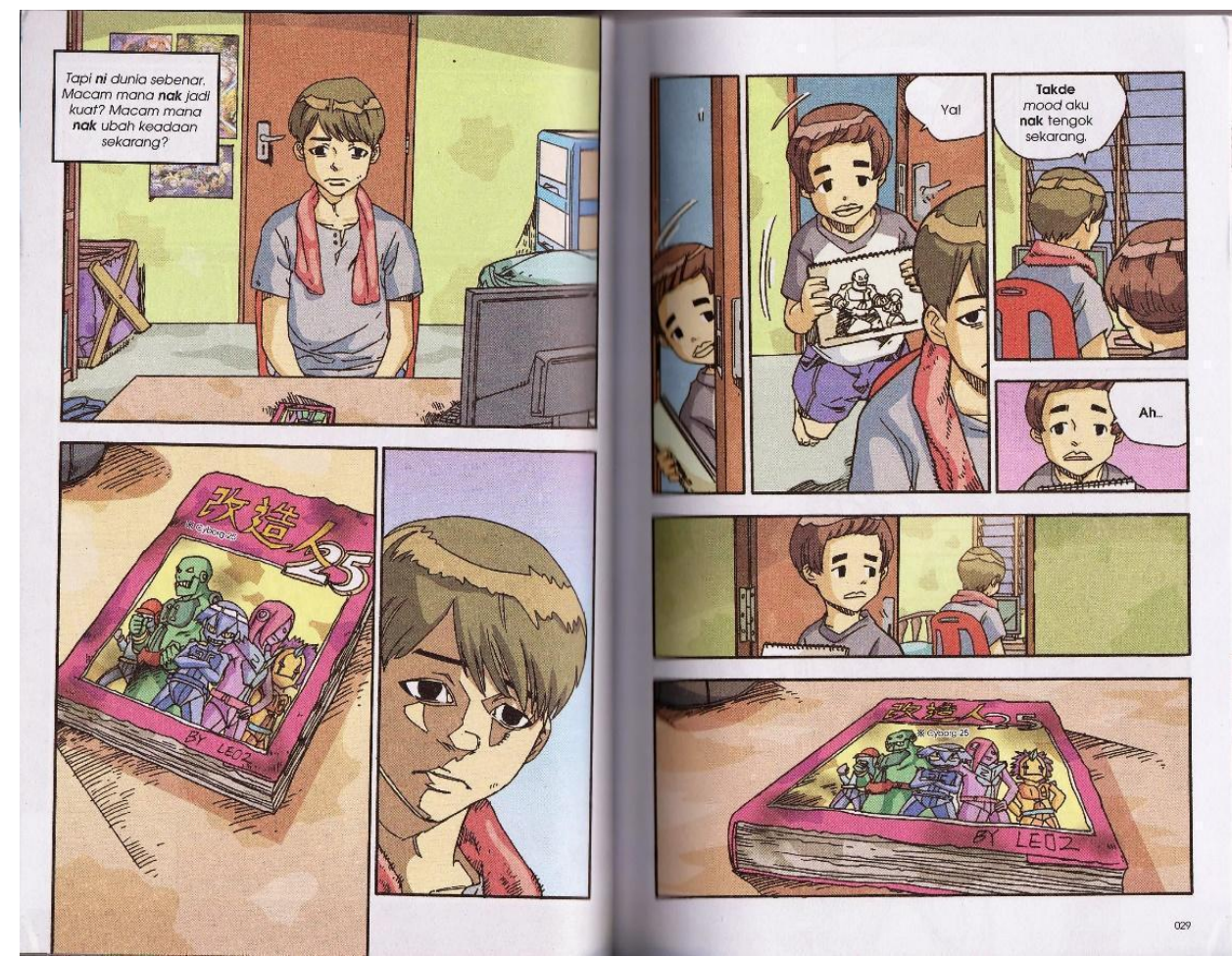

Figure 5 - The condition of Joel's house is basic and spartan, but he and Pico collect comic books.

(Image scanned from Kepahitan Tersembunyi [Dreamerz \& Leoz, 2016].)

However, Joel and his younger adopted brother Pico both can afford to collect comic books and video games, suggesting they are not in dire need of money. Joel goes to a mainstream national secondary school (this suggests the majority of lessons are conducted in Bahasa Malaysia, the country's official language), Sekolah Menengah Kebangsaan Bukit Hitam. This also implies that 
the school is multi-ethnic. The bullies come from rich families (with one being called "young master"). Later on, Joel becomes a school teacher while Pico becomes a manga artist in Japan, indicating intergenerational social mobility.

\section{Family $\mathcal{E}$ Relationships}

Joel lives with his father, Mr. Lee, a "wantan mee" noodle seller, and his mute younger adopted brother, Pico. Joel's mother passed away from heart disease. Pico was adopted as he was the son of a family friend who is of Japanese ethnicity. He is rendered mute due to the trauma of witnessing his parents' death in a house fire. Pico adores Joel, but Joel views Pico as a nuisance. Joel and Mr. Lee take notice of Pico's talent in drawing fan art of their favourite manga (which surpasses Joel's ability).
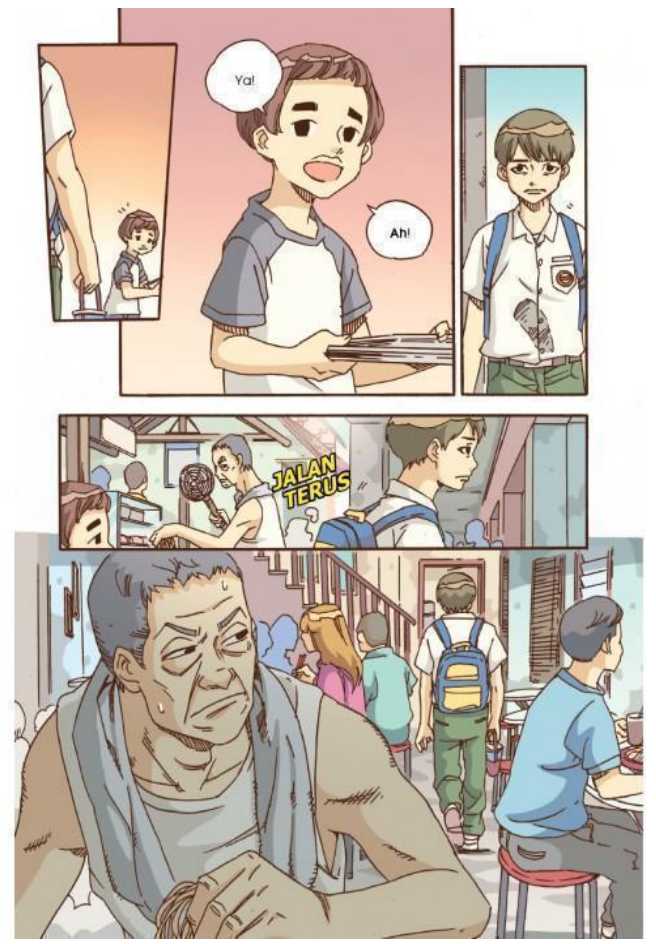

Figure 6 - Main character Joel, his younger adopted brother Pico, and their father, Mr. Lee

(Image scanned from Kepahitan Tersembunyi [Dreamerz \& Leoz, 2016].)

Mr. Lee misses his wife and does not know what to do without her, as he perceives Joel is lazy and unwilling to help at his stall, even though Pico does so. Formerly Joel had been close to his mother, who was a caring and nurturing 
figure. Meanwhile, Joel is facing his own demons as he is bullied frequently and takes out his frustration by playing video games and by being unfriendly to Pico. But Mr. Lee does not understand this and often scolds Joel. Later on, aggravated by news of Joel beating up the bullies, Mr. Lee ends up hospitalised because of a stroke. Joel is grappling with the idea of the "survival of the fittest" as a way to overcome his problem with the bullies. When Joel is bullied, Wendy, his schoolmate, always comes to his rescue, and they date for a while.

\section{Gender}

Unlike stereotypical representations of "damsels in distress", the main female character, Wendy who is also Joel's love interest, is portrayed as his saviour. She is the one who champions his cause when he feels let down by the authority figures in his life (e.g. his father, the prefects, the school teacher). Wendy is brave enough to stand up to the bullies and later, to Joel when he starts bullying others. Wendy wears a girls' uniform but is depicted as having short androgynous hair which she still keeps when she is an adult. She outs the bullies to the teacher, who at first does not believe her as the bullies are star student athletes.
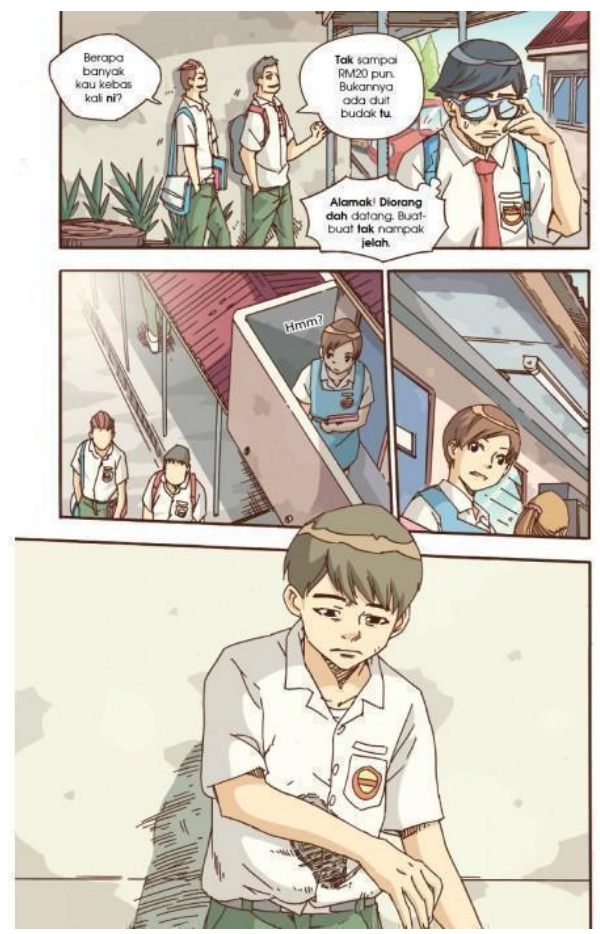

Figure 7 - Joel is bullied, the school prefect refuses to help, but classmate Wendy comes to the rescue.

(Image scanned from Kepahitan Tersembunyi [Dreamerz \& Leoz, 2016].) 
Wendy is the voice of moral concern when Joel later changes into a bully himself. She later gives a speech in school against bullying, earning admiration from students and teachers. In the end of the manga, Joel and Wendy are still friends though not a couple. She is described as having a career as a public relations manager. Aside from Wendy, other characters appear to be genderrole conformist (boys acting tough, fathers/male teachers being strict, mothers being caring, etc.) with the issue of hegemonic masculinity seeming to be the main theme.

\section{Power}
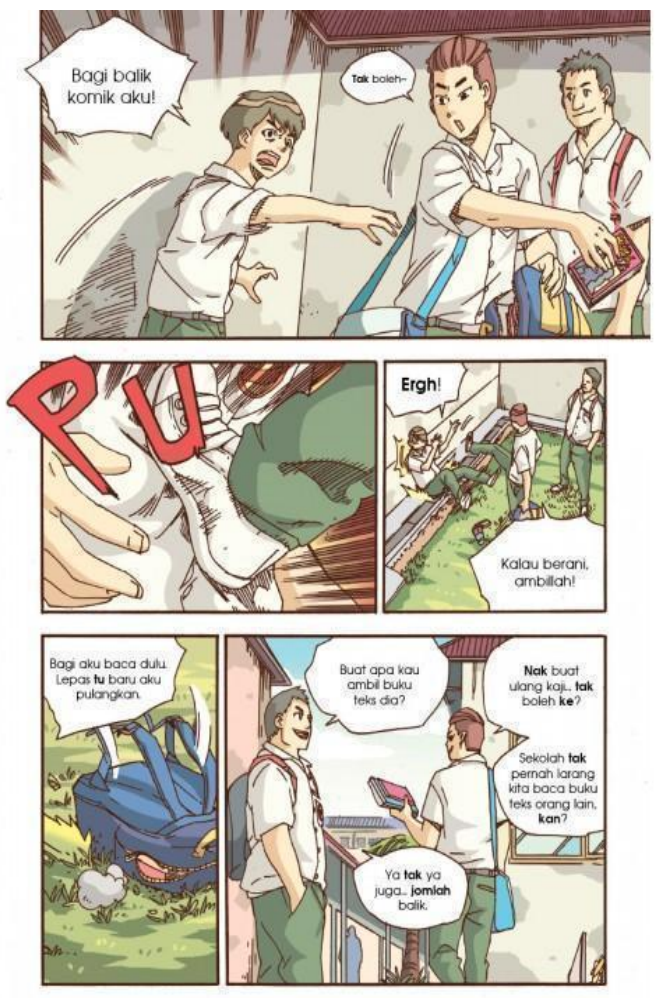

Figure 8 - The bullies snatch away Joel's comic books and make fun of his poverty.

(Image scanned from Kepahitan Tersembunyi [Dreamerz \& Leoz, 2016].)

Joel, the main character is a bully victim. School prefects exist but they are afraid to interfere because they might be targeted too. The bullies come from upper-class families and are star students in sports. The class teacher is a typical 
authoritarian figure who orders his students to sit down as the class is about to start. He also does not appear to care for or to investigate the reasons for Joel wearing sportswear instead of his school uniform and not bringing his textbooks to school (they were taken by the bullies). Instead, Joel is punished to stand outside the classroom. He also believes and reinforces stereotypes that star students do not bully anyone. This is quashed by Wendy. Joel feels let down by the authority figures in his life (e.g. his father, the schoolteacher, the prefects).

Joel is toying with the idea of "survival of the fittest" as he is bullied. When the bullies get too extreme, he is unable to take it anymore and snaps. He brings a baseball bat to school and beats them up. He then gains a newfound status. Later on, to avoid ever being bullied again, Joel starts bullying others instead. However, in the end, after he is redeemed and becomes a schoolteacher, Joel protects his students by confronting their bullies.

\section{Moral Values}

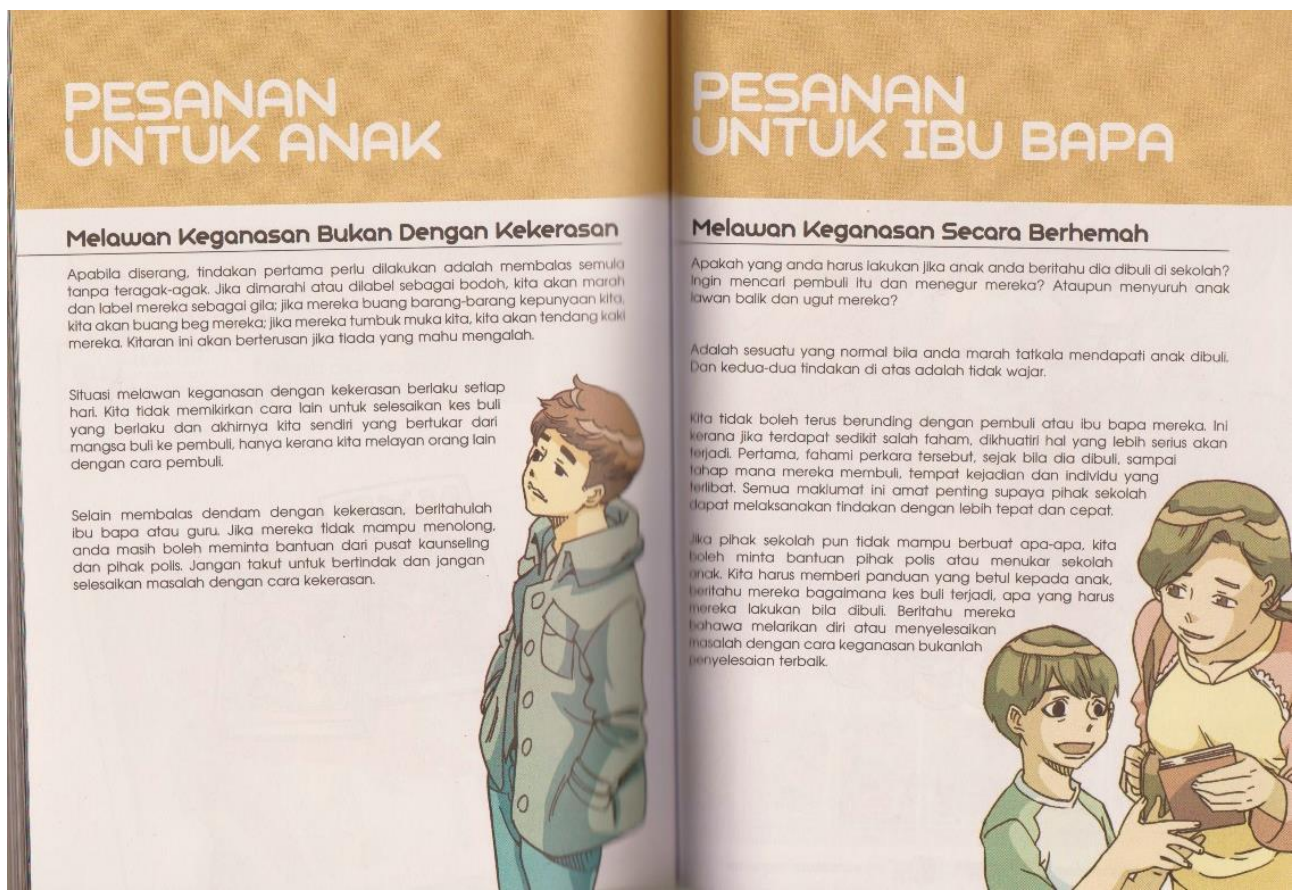

Figure 9 - Moral messages are included, and on this page, they are literally spelt out for children and parents. Message for children: Do not fight violence with violence. Message for parents: Fight violence ethically.

(Image scanned from Kepahitan Tersembunyi [Dreamerz \& Leoz, 2016].) 
Wendy is often the voice of reason to Joel. Wendy gives Joel RM 10 when she sees him now oppressing others for money. At the climax of the story, Joel's bullies (who were beaten up by him) seek revenge. They corner him in an abandoned house when he is trying to burn old mementos (after Wendy appears to dump him for bullying others). A fire starts. Pico, who saw his brother stuck in the burning building, eventually overcomes his inability to speak (as he became mute after seeing his parents die in a fire). Pico saves Joel's life by screaming for help.

Pico willingly takes the fall for Joel by claiming he started the fire. Joel is touched by Pico's actions and later turns himself in. He is sent to rehab school due to his young age. Mr. Lee confesses that he is sorry for being harsh and unsupportive of Joel's interests, to Wendy when she visits him at the hospital. The relationship between Joel and Pico and their father improves. In the end, Joel has become a school teacher, and cares deeply about his students. He also punishes bullies and encourages a student who likes manga to become a manga artist, while thinking about Pico who is now a manga artist.

\section{"Japanese-ness"}

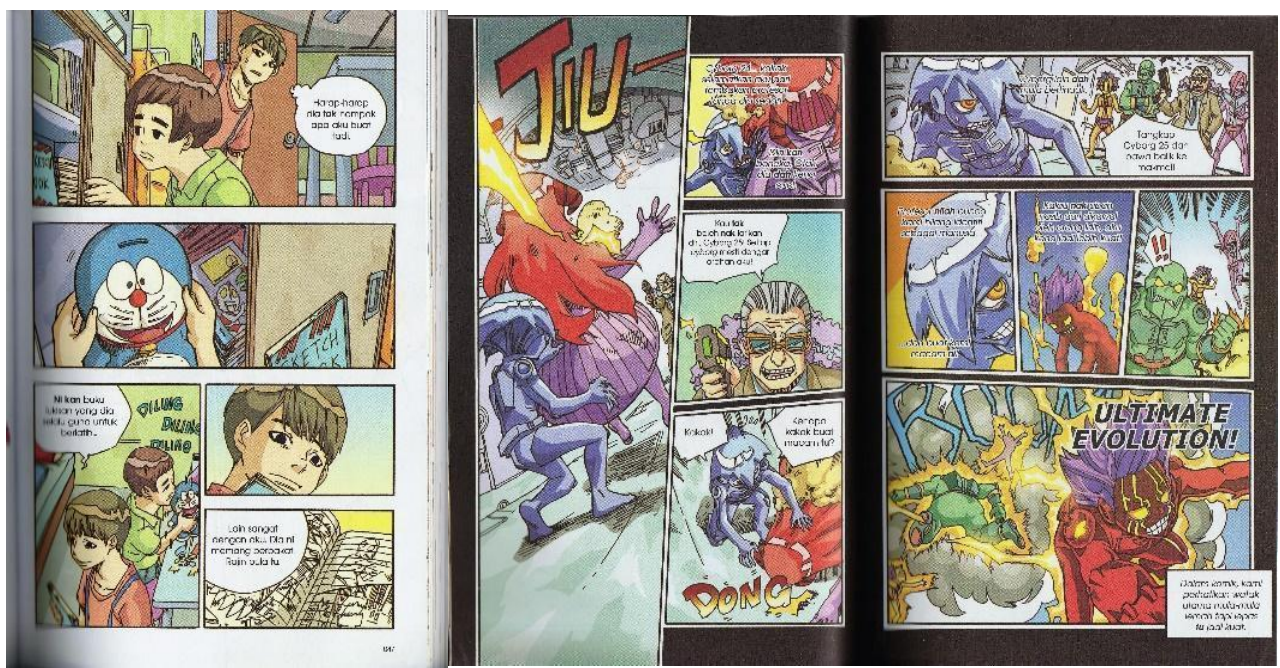

Figure 10 - There is a Doraemon coinbox and a preview of Joel and Pico's favourite Japanese mecha manga.

(Image scanned from Kepahitan Tersembunyi [Dreamerz \& Leoz, 2016].)

There are many tributes to Japanese manga within the comic. A Doraemon coin box is clearly shown in one panel. Joel and Pico love a certain manga about mecha, and this manga is excerpted. Joel and Pico also play video 
games. The bullies bully Joel because he reads the manga, but they seize the manga and read them too. Pico is of Japanese ethnicity. He is also very gifted at drawing manga. At the end of the story, he has become a manga artist based in Tokyo. Towards the end, Joel is a schoolteacher. He and his colleagues openly enjoy manga. He encourages a student who wants to become a manga artist. His female colleague, who is implied to be his girlfriend also displays an interest in manga.

\section{Relevance to Social Issues}

The manga also highlights important social issues relating to its targeted readers, which is the issue of bullying in schools. While it is acknowledged that bullying happens anywhere, everywhere, regardless of social institution, age, gender, social class, or ethnicity, data for Malaysia showed that the rate of bullying on one or more days during the past 30 days for Malaysian students was $20.9 \%$ for $13-15$ year olds (males 24.0 , females 17.8 ), and $12.5 \%$ for $16-17$ year olds (males 12.9, females 12.0) (Sittichai \& Smith, 2015).

\section{Discussion and Conclusion}

\section{Malaysian comic history}

As seen from the above evidence, I argue that Dreamerz's and Leoz's Kepahitan Tersembunyi represents a "domesticated" form of original Malaysian manga through its identification of ethnicity, education system, and social class among others, though it also acknowledges its Japanese influences through the insertion of iconic manga and anime characters such as Doraemon and the fictional mecha.

Malaysian society is multi-ethnic and multilingual. According to sociologist Chan, "Malaysia has a multicultural social context, comprising several main ethnic groups, often classified as the Malays, the Chinese and the Indians (Hirschman 1986, p. 555; Chan, 2018b); as well as the indigenous groups whose majority is the Semai (Arabestani \& Edo, 2011, p. 6; Chan, 2018b), and in East Malaysia the KadazanDusun (Defense Language Institute, 2015, p. 62; Chan, 2018b). However, these categorisations have been said to be a legacy of colonial discourse, and thus in its post-colonial climate, it is pertinent to analyse the effects of such discourse by focusing on popular narratives, which include cartoons, songs, poems, and other unofficial discourses (Shamsul Amri Baharuddin \& Athi S. M., 2013, p. 268a). In addition, Voon (1998) observed that Asian countries, including Malaysia, had broken out of its state of "timelessness" 
since the rise of Japan in the 1980s, with its cultural perspective deeply in need of attention by scholars.

Anime or manga has the potential as a platform in contributing to the establishments of national identity from the everyday-defined approach, as it is a reflection of folks' lifestyle via a set of signs and symbols in the cultural industry (Faryna Mohd Khalis, Normah Mustaffa, \& Mohd Nor Shahizan Ali, 2016). In addition, Yamato (2016) observes that anime, comics, and games (ACG) activities have captured the attention of Malaysian youth and have the potential to become grounds for personal development.

To appreciate the significance of Dreamerz's and Leoz's Kepahitan Tersembunyi, we have to first understand the history of comics development in Malaysia. Lent chronicled the evolution of comics development in Malaysia, which extends beyond manga into other forms of comics (Lent, 2015). Lent noted that comic art in Malaysia has had to fit into a complex geographical, political system, outlining three spatial-temporal issues (Lent, 2015):

1. During the British colonial period up to the 1960s when Malaysia and Singapore were politically intertwined.

2. Malaysia is multiethnic and multilingual, and its comics have appeared in Malay, English, Chinese, and Tamil.

3. Malaysia consists of West Malaysia and East Malaysia.

The evolution of Malaysian cartoon art can be categorised into four main periods (Muliyadi Mahamood, 2012). These are the Pioneer Era (the 1930s to 1957, or Malaysia's Independence from the British), the New Era (1957 to 1970s), the Glory Era (the 1980s), and the Pluralist Era (since the 1990s) (Muliyadi Mahamood, 2012). Dreamerz's Leoz's Kepahitan Tersembunyi falls under the Pluralist Era. Throughout these phases, comics in Malaysia had evolved in its genres, styles, themes, forms and meaning (Muliyadi Mahamood, 2012). Comics in Malaysia enjoyed a magnitude of recognition in the late 1970s, starting with the establishment of humor magazines such as Gila Gila in 1978 (Lent, 1994). Throughout the 1980s and 1990s, humor and satire had become publicly popular in Malaysia due to this (Lent, 1994). However, many other similar magazines began to sprout, and eventually, by 1990, the humor market had become saturated, leading to the folding of many magazines (Lent, 1994). Only four humor magazines remained in 1994 (Lent, 1994).

Gempak Magazine, the first to exclusively publish manga, originally started out as a publishing and advertising company in the early 1990s called The Art Square Group (Lent, 2015). The magazine later developed a strong 
manga influence, with 65 percent of manga content, in terms of illustrative style, settings, characters, and plot lines. By 2012, Art Square had published about 500 graphic novels with 60 percent of them locally produced. Kadokawa Corp from Tokyo now owns an 80 percent stake in Art Square Group ("Kadokawa of Japan to use Malaysia as a launchpad to S-E Asia and the Middle East", 2015). They currently own Gempak Starz, which is the stable of comic artists including Kaoru and Leoz.

Aside from this, a case study by Tan of the small but present Malaysian Chinese comic scene reveals that one of its discerning characteristics is the incorporation of unique heritage and culture, such as the kampung or village houses, traditional games, food, and language of Malaysians (Tan, 2014). Despite this, Tan concludes that Malaysian Chinese comics, though produced by Malaysian Chinese authors and written in Chinese, does not fulfil the three criteria of style, i.e. unique illustration, content, and culture, and thus does not constitute a fully developed contemporary comic style (Tan, 2014). While the Malaysian Chinese comic scene emerged in the 1970s and reached its peak in 1980, it faced a challenge too from the burgeoning influence of Japanese comics in the 1990s (Tan, 2014). Dreamerz's and Leoz's Kepahitan Tersembunyi bears some resemblance in content to this Malaysian Chinese wave of comics due to its depictions of Chinese ethnicity and the working class stereotype as an axis of discourse.

Japanese manga has also been noted for its unique vantage point, differing from the dominant Western comic forms. Cohn analysed the differences in American comics and Japanese manga, finding that they differ in their trends of highlighting characters, depicting subjective viewpoints, and varying spatial angles, attributing it to "visual language". American comics show the full scene more often (Macro panels), while Japanese manga show less than a full scene (Mono and Micro panels) more often (Cohn, 2011). Japanese panels appear to detail aspects of the broader environment, leaving the rest to the reader's imagination (Cohn, 2011). As American comics feature more action scenes, the use of more Macro panels and transition panels is justified (McCloud, 1993, in Cohn, 2011). Using this finding, Cohn also echoes McCloud's observation that Japanese manga provides a more "subjective" experience for the reader (McCloud, 1993). This suggests that Japanese manga as a medium has the potential to serve as a springboard for one's imagination in taking the perspective of "the other", such as in the case of empathising with a character who is being bullied.

Yamato (2014) highlights several issues in interpreting "Japanese-ness" in Malaysian manga consumption following Iwabuchi's concept of 
"nationless"-ness and "culturally odourless" ness (Iwabuchi, 1998). In her interviews with respondents, she found that there was "individual proximity" (after Straubhaar) in respondents' favourite media texts (Straubhaar, 2008 [as cited in Georgiou, 2012]; Yamato, 2014). This suggests that transnational media texts of Japanese popular culture may be potential materials for reflecting and discussing the "individual proximity" in people, social issues, or phenomenon (rather than "essential culture" which is linked to the national/ethnic origin). Indeed, Roslina Mamat, Roswati Abdul Rashid, Normaliza Abd Rahim and Hazlina Abdul Halim found that among secondary school students in the state of Selangor in Malaysia, they claimed to favour manga characters based on five features, which are bravery, industriousness, importance of family and friendship, a sense of humour, and special abilities (Roslina Mamat, Roswati Abdul Rashid, Normaliza Abd Rahim, \& Hazlina Abdul Halim, 2014). Although younger generation Malaysians are influenced by Japanese and Western character designs (Khalid, 2010), it is possible to steer them towards a local touch through education (Faryna Mohd Khalis \& Normah Mustaffa, 2017).

In Malaysia, the benefits of using comics or graphic novels as educational platforms have also been documented as of late. Thusha Rani Rajendra made a case for including graphic novels as a wholesome supplement in Malaysian schools through the benefits of multimodal texts (Rajendra, 2015). Hadi Akbar Bin Dahlan, Norrakiah Abdullah Sani, and Nor Rofeah Abdullah Sani noted how comics is a tool made with the purposes of conveying moral values and academic content, to promote inquisitive skills within readers (Hadi Akbar Bin Dahlan, Norrakiah Abdullah Sani, \& Nor Rofeah Abdullah Sani, 2015). For example, in Malaysia, Moral Education (ME) has been a subject taught in the Malaysian education system for more than two decades (Vishalache Balakrishnan, 2010). Moral Education emphasises the importance of good moral values such as 'responsibility', a dominant value for achieving national unity in multi-ethnic Malaysia (Tan, Noor Banu Mahadir Naidu, \& Zuraini Jamil Osman, 2018).

In conclusion, one can observe that original Malaysian manga has transcended the "culturally odourless" form of its progenitor, the Japanese manga. With that said, local manga artists such as Leoz do make an effort to acknowledge the Japanese origins of their inspirations. Malaysian original manga has now become more than just entertainment material but a platform to voice out concerns through a dramaturgical stage. Its readers have overcome a mere fetishisation of a foreign cultural product into accepting it as a locally adaptable medium of channeling identity-based discourse. The negotiation of identity from an "everyday-defined" perspective can take place through the 
discourse originated in these platforms. As Lent claimed, to stereotype Asian comics is a futile exercise, because they come in various sizes, formats, and genres (Lent, 2015). The issues surrounding Malaysian comic history have affected comic art in that multi-ethnicity has determined storytelling, plot, and character development, and set limits on how the different cultures' issues and personalities have been depicted (Lent, 2015).

\section{Acknowledgement}

This research work is supported by the National University of Malaysia (UKM) under Grant Numbers UKM GGP-2017-008 (Migration and Superdiversity: A new concept and challenges for national integration), and UKM AP-2017-001/1 (Platform Integrasi: Pendekatan 'Top-down' dan 'Bottom-up' dalam mendepani cabaran kesepaduan social).

\section{References}

Allison, A. (2000). Sailor Moon: Japanese superheroes for girls. In T. J. Craig (Ed.), Japan pop! Inside the world of Japanese popular culture (pp. 259-278). New York: M.E. Sharpe.

Arabestani, M., \& Edo, J. (2011). The Semai's response to missionary work: From resistance to compliance. Anthropological Notebooks, 17(3), 5-27.

Balakrishnan, V. (2010). The development of moral education in Malaysia. Journal of Educators \& Education/Jurnal Pendidik dan Pendidikan, 25, 89-101.

Brenner, R. E. (2007). Understanding Manga and Anime. Connecticut: Greenwood Publishing Group.

Brienza, C. (Ed.). (2015). Global manga: "Japanese" comics without Japan? UK: Ashgate Publishing Limited.

Bryce, M., Barber, C., Kelly, J., Siris Kunwar, \& Plumb, A. (2010). Manga and anime: Fluidity and hybridity in global imagery. Electronic Journal of Contemporary Japanese Studies. Retrieved from http://www.japanesestudies.org.uk/articles/2010/Bryce.html

Chan, R. S. K. (2017). Game of translations: Virtual community doing English translations of Chinese online fiction. Journal of Science and Technology of the Arts, 9(1), 39-55.

Chan, R. S. K. (2018a). "Expressive Rationality": Habitus and field in a Malaysian cosplay community. International Journal of Asia-Pacific Studies, 14(1), 133163. Retrieved from https://doi.org/10.21315/ijaps2018.14.1.6 
Chan, R. S. K. (2018b). In between worlds: The convergence of Chinese and Western values as global habitus. JATI- Journal of Southeast Asian Studies, 23(1), 156-190. Retrieved from https://doi.org/10.22452/jati.vol23no1.8

Cohn, N. (2008). Japanese Visual Language: The Structure of Manga. In Manga: The Essential Reader. London \& New York: Continuum Books.

Cohn, N. (2011). A different kind of cultural frame: An analysis of panels in American comics and Japanese manga. Image E Narrative, 12(1), 120-134.

Defense Language Institute. (2015). Malaysia in perspective: An orientation guide. $\quad$ Retrieved from http://fieldsupport.dliflc.edu/products/cip/Malaysia/malaysia.pdf

Douglass, J., Huber, W. \& Manovich, L. (2011). Understanding scanlation: How to read one million fan-translated manga pages. Image $\mathcal{E}$ Narrative, 12(1), 206-228.

Dreamerz, \& Leoz. (2016). Kepahitan Tersembunyi. Kuala Lumpur: Gempak Starz. Faryna Mohd Khalis, \& Normah Mustaffa (2017). Cultural inspirations towards Malaysian animation characters. Jurnal Komunikasi, 33(1), 487-501.

Faryna Mohd Khalis, Normah Mustaffa, \& Mohd Nor Shahizan Ali. (2016). The sense of local identity characteristic in Malaysian animation. International Journal of Arts E Sciences, 9(3), 485-496.

Fusanosuke, N. (2003). Japanese manga: Its expression and popularity. $A B D$, $34(1), 3-5$.

Gan, S. H. (2011). Manga in Malaysia: An approach to its current hybridity through the career of the shojo mangaka Kaoru. International Journal of Comic Art, 13(2), 164-178.

Georgiou, M. (2012). Watching soap opera in the diaspora: Cultural proximity or critical proximity? Ethnic and Racial Studies, 35(5), 868-887.

Gravett, P. (2004). Manga: Sixty years of Japanese comics. London: Laurence King. Hadi Akbar bin Dahlan, Norrakiah Abdullah Sani, \& Nor Rofeah Abdullah Sani. (2015). Comic as an education tool. In Proceedings of FEIIC-International Conference on Engineering Education \& Research 2015, Madinah, Saudi Arabia, 19-21 December.

Helios Eclipse. (n.d.). In Wikipedia Bahasa Melayu. Retrieved September 4, 2018, from https://ms.wikipedia.org/wiki/Helios_Eclipse

Hirschman, C. (1986). The making of race in colonial Malaya: Political economy and racial ideology. Sociological Forum, 1(2), 330-361. Retrieved from https://doi.org/10.1007/BF01115742

Iwabuchi, K. (1998). Marketing Japan: Japanese cultural presence under a global gaze. Japanese Studies, 28, 165-180. 
Johnson-Woods, T. (Ed.) (2010). Manga: An Anthology of Global and Cultural Perspectives. New York: Continuum Books.

Kadokawa of Japan to use Malaysia as launchpad to S-E Asia and Middle East. (2015, 10 December). The Star Online. Retrieved from https:/www.thestar.com.my/business/businessnews/2015/12/10/kadokawa-of-japan-to-use-malaysia-as-launchpad-tose-asia-and-middle-east/

Kaoru's official Facebook page. (n.d.). Retrieved from https://www.facebook.com/kaorupage/

Kaoru (pelukis komik). (n.d.). In Wikipedia Bahasa Melayu. Retrieved September 4, 2018, from https://ms.wikipedia.org/wiki/Kaoru_(pelukis_komik)

Kaoru's Cake House. (n.d.). In Wikipedia Bahasa Melayu. Retrieved September 4, 2018, from https://ms.wikipedia.org/wiki/Kaoru\%27s_Cake_House

Kaoru's romantic comics, or Shojo manga, are hits. (2016, 29 July). Star2.com.

Retrieved from https:/www.star2.com/living/comics/2016/07/29/kaorusromantic-comics-or-shojo-manga-are-hits/\#GG8vBWx2zHRAHBJc.99

Khalid, M. N. (2010). The Kampung Boy. Kuala Lumpur: Berita Publishing Sdn. Bhd.

Kinsella, S. (2000). Adult manga. Honolulu: University of Hawaii Press.

Lee, J. (2018). Domesticating the global: Manga beyond Japan. International Journal of Communication, 12, 1761-1763.

Lent, J. A. (1994). Of "Kampung Boy", "Tok Guru", and other zany characters: Cartooning in Malaysia. Jurnal Komunikasi, 10, 55-77.

Lent, J. A. (2007). Southeast Asian cartooning: An overview. SPAFA Journal, 17(1), 7-12.

Lent, J. A. (2015). Asian Comics. Mississippi: University Press of Mississippi.

Levi, A. (2006). The Americanization of anime and manga: Negotiating popular culture. In S. T. Brown (Ed.), Cinema anime: Critical engagements with Japanese animation (pp. 43-63). New York: Palgrave Macmillan.

Maid Maiden. (n.d.). In Wikipedia Bahasa Melayu. Retrieved September 4, 2018, from https://ms.wikipedia.org/wiki/Maid_Maiden

Muliyadi Mahamood. (2012). The role of cartoon in the formation of Asian community: Art history analysis. HISTORIA: International Journal of History Education, 13(1), 119-130.

McCloud, S. (1993). Understanding Comics: The Invisible Art. New York: Harper Collins.

Napier, S. J. (2007). From impressionism to anime: Japan as fantasy and fan cult in the mind of the west. New York: Palgrave Macmillan. 
Newitz, A. (1995). Magical girls and atomic bomb sperm: Japanese animation in America. Film Quarterly, 49(1), 2-15.

Norris, C. (2005). Cyborg girls and shape-shifters: The discovery of difference by anime and manga fans in Australia. Refractory: A Journal of Entertainment Media, 8 Retrieved from http://refractory.unimelb.edu.au/2005/10/14/cyborg-girls-and-shapeshifters-the-discovery-of-difference-by-anime-and-manga-fans-inaustralia-craig-norris/

Rajendra, T. R. (2015). Multimodality in Malaysian schools: The case for the graphic novel. Malaysian Online Journal of Educational Sciences, 3(2), 11-20.

Roslina Mamat, Roswati Abdul Rashid, Normaliza Abd Rahim, \& Hazlina Abdul Halim. (2014). Imej karakter animasi Jepun (anime) dalam kalangan remaja di Selangor. Sains Humanika, 67(1), 39-43.

Roslina Mamat, Yamato Eriko, Sanimah Hussin, \& Farah Tajuddin. (2012). Anime viewing among secondary school students in Malaysia. Global Media Journal - Malaysian Edition, 2(2), 40-60.

Schodt, F. L. (1983). Manga! Manga! The World of Japanese Comics. New York: Kodansha America Inc.

Shamsul Amri Baharuddin. (1996). Debating about identity in Malaysia: A discourse analysis. Southeast Asian Studies, 3(3), 476-499.

Shamsul Amri Baharuddin \& Athi, S.M. (2013) Ethnicity and identity formation: Colonial knowledge, colonial structures and transition. In M.L. Weiss (Ed.), Routledge handbook of contemporary Malaysia (pp. 267-278). Oxford: Routledge.

Sittichai, R. \& Smith, P., (2015). Bullying in south-east Asian countries: A review. Aggression and Violent Behavior, 23, 22-35.

Straubhaar, J. D. (2008). Global, hybrid or multiple? Cultural identities in the age of satellite TV and the Internet. Nordicom Review, 29(2), 11-30.

Tan, B. P., Noor Banu Mahadir Naidu, \& Zuraini Jamil Osman. (2018). Moral values and good citizens in a multi-ethnic society: A content analysis of moral education textbooks in Malaysia. The Journal of Social Studies Research, 42(2), 119-134.

Tan, W. L. (2014). Study on contemporary Malaysian Chinese comic to investigate whether the Malaysian comic style has emerged - Bachelor's Dissertation, KDU International College Malaysia in collaboration with Nottingham Trent University.

Wanna Dance with You. (2009). Gempak Malaysia's Comic! Retrieved from http://locallycomical.blogspot.com/2009/10/wanna-dance-with-you.html 
Wong, W. S. (2006). Globalizing manga: From Japan to Hong Kong and beyond. Mechademia, 1(1), 23-45.

Yamato, E. (2014). Cultural proximity and reflexivity in interpreting transnational media texts: The case of Malaysians consuming Japanese popular culture. The Qualitative Report, 19(47), 1-20.

Yamato, E. (2016). Growing as a person: Experiences at anime, comics, and games fan events in Malaysia. Journal of Youth Studies, 19(6), 743-759.

Voon, P. K. (1998). Asian studies in Malaysia: An overview. JATI - Journal of Southeast Asian Studies, 4, 1-15. Retrieved from https://mjlis.um.edu.my/index.php/jati/article/view/6476/4173 